UCRL-JC-121405

PREPRINT

\title{
Capacitive Deionization with Carbon Aerogel Electrodes: Carbonate, Sulfate, and Phosphate
}

\author{
J. C. Farmer \\ D. V. Fix \\ G. V. Mack \\ R. W. Pekala \\ J. F. Poco
}

This paper was prepared for submittal to the 27th International Society for the Advancement of Materials

Process Engineers Technical Conference

Albuquerque, NM

October 9-12, 1995

July 24, 1995

This is a preprint of a paper intended for publication in a journal or proceedings. Since changes may be made before publication, this preprint is made available with the understanding that it will not be cited or reproduced without the permission of the author. 


\section{DISCLAMER}

This document was prepared as an account of work sponsored by an agency of the United States Government. Neither the United States Government nor the University of California nor any of their employees, makes any warranty, express or implied, or assumes any legal liability or responsibility for the accuracy, completeness, or usefulness of any information, apparahs, product, or process disclosed, or represents that its use would not infringe privately owned rights. Reference herein to any specific commercial product, process, or service by trade name, trademark, manufacturer, or otherwise, does not necessarily constitute or imply its endorsement, recommendation, or favoring by the United States Government or the University of California. The views and opinions of authors expressed herein do not necessarily state or reflect those of the United States Government or the University of California, and shall not be used for advertising or product endorsement purposes. 


\section{DISCLAIMER}

Portions of this document may be illegible electronic image products. Images are produced from the best available original document. 


\title{
Capacitive Deionization with \\ Carbon Aerogel Electrodes: Carbonate, Sulfate, and Phosphate
}

\author{
Joseph C. Farmer, David V. Fix, Gregory V. Mack, \\ Richard W. Pekala, and John F. Poco \\ Lawrence Livermore National Laboratory \\ Livermore, California 94551
}

\begin{abstract}
A process for the capacitive deionization of water with a stack of carbon aerogel electrodes has been developed by Lawrence Livermore National Laboratory. Unlike ion exchange, one of the more conventional deionization processes, no chemicals are required for regeneration of the system. Electricity is used instead. Water with various anions and cations is pumped through the electrochemical cell. After polarization, ions are electrostatically removed from the water and held in the electric double layers formed at the surfaces of electrodes. The water leaving the cell is purified, as desired. The effects of cell voltage on the electrosorption capacities for $\mathrm{Na}_{2} \mathrm{SO}_{4}, \mathrm{Na}_{3} \mathrm{PO}_{4}$, and $\mathrm{Na}_{2} \mathrm{CO}_{3}$ have been investigated and are reported here. Results for $\mathrm{NaCl}$ and $\mathrm{NaNO}_{3}$ have been reported previously.
\end{abstract}

\section{INTRODUCTION}

A process for the capacitive deionization (CDI) of water with a stack of carbon aerogel electrodes has been developed by Lawrence Livermore National Laboratory. Aqueous solutions of $\mathrm{Na}_{2} \mathrm{SO}_{4}, \mathrm{Na}_{3} \mathrm{PO}_{4}$, or $\mathrm{Na}_{2} \mathrm{CO}_{3}$ are passed through a stack of carbon aerogel electrodes, each having an exceptionally high specific surface areas $\left(400-1000 \mathrm{~m}^{2} / \mathrm{gm}\right)$. After polarization, non-reducible and non-oxidizable ions are removed from the electrolyte by the imposed electric field and held in electric double layers formed at the surfaces of electrodes. As desired, the effluent from the cell is purified water. This process is also capable of simultaneously removing a variety of other impurities. For example, dissolved heavy metals and suspended colloids can be removed by electrodeposition and electrophoresis, respectively. CDI has several potential advantages over other more conventional technologies. Unlike ion exchange, no acids, bases; or salt solutions are required for regeneration of the system. Regeneration is accomplished by electrically discharging the cell. Therefore, no secondary waste is generated. In contrast to thermal processes such as evaporation, CDI is more energy efficient. Since no membranes or high pressure pumps are required, CDI may offer operational advantages over electrodialysis and reverse osmosis (RO).

\section{BACKGROUND}

Several publications and patents have appeared that discuss the use of porous electrodes for the recovery of heavy metals from aqueous solutions [1-8]. In these cases, metallic ions are electrodeposited on the surfaces of cathodes with relatively low specific surface areas. Since deposits can be several atomic layers thick, high specific surface areas are not required. Reticulated vitreous carbon (RVC) foam has been found to be adequate for such applications.

The first studies published on capacitive deionization appeared around 1966. Caudle et al. used porous flow-through electrodes made of activated carbon powder to desalinate water $[9,10]$. Johnson et al. conducted similar studies of reversible electrosorption, or capacitive 
deionization, and published their work in 1970 [11-13]. Their experimental program included verification of the theoretical basis for the process, parametric studies, and evaluation of a variety of candidate electrode materials. Johnson's work prompted Newman to develop a comprehensive theoretical model for the capacitive charging of porous carbon electrodes [14]. Unfortunately, CDI was eventually abandoned by Johnson due to various problems, including the failure to demonstrate degradation-free electrode performance. However, preliminary cost studies did indicate that an efficient, low-cost desalination plant based upon this technology could be built if adequate durability of the electrodes could be achieved. Since this work was conducted decades before the invention of carbon aerogel electrodes, such materials were not included in the study. Several years later, work on CDI was done in Israel and published in 1983 [15-17]. They used a CDI system similar to that described by Johnson et al. for the removal of $\mathrm{NaCl}$ from water. A column was built from two separated beds of activated carbon, one serving as the anode and the other serving as the cathode. Concentration ratios as high as $1 / 100$ were attained between the top and the bottom of the column. They also developed a theoretical model to predict process performance.

Previous CDI systems used flow-through beds of activated carbon as electrodes. The beds were separated by appropriate membrane separators. Raw water was flown along the axial direction of the carbon beds. Several important practical problems are inherent in such cells. First and foremost, axial flow through such packed beds can result in significant pressure drop. Activated carbon appropriate for use in a flow-through packed bed has a relatively low specific surface area. Since the carbon powder cannot be immobilized, beds must be physically separated by porous membranes. Even so, carbon particles and fines, smaller particles generated by erosion of the primary particles, can become entrained in the flow, thereby depleting the bed. Since these carbon electrodes are quite thick, a large potential drop also develops, thereby lowering process efficiency. Even though adjacent carbon particles may touch, intimate electrical contact may not exist. Consequently, a significant electrical resistance may develop.

Numerous supercapacitors based on various porous carbon electrodes, including carbon aerogel electrodes, have been developed for energy storage applications [18-23]. However, none of these devices were designed to permit electrolyte flow and most required membranes to physically separate the electrodes. A double-layer capacitor with a porous activated carbon electrode was developed by Nippon Electric Company of Japan [18]. An electrically conductive layer of activated carbon powder dispersed in butyl rubber, butadiene rubber, polyisoprene, or their copolymers and derivatives was coated onto one side of a current collector. High performance electrodes for double-layer capacitors based on activated carbon fibers were developed by Matsushita Electric Industrial Company [19]. NEC Corporation also developed activated carbon-carbon composite electrodes for a double-layer capacitor [20]. Apparantly, the first electrodes made of carbonized foamed phenol resin for application in energy storage capacitors were developed by Mitsui Petrochem [21]. Subsequently, a wide variety of microcellular carbon foams for application in double-layer capacitors were prepared and evaluated by Sandia National Laboratory [22]. These materials were prepared by the controlled pyrolysis and carbonization of several polymers including polyacrylonitrile, polymethacrylonitrile, resorcinol-formaldehyde, divinylbenzene-methacrylonitrile, furfurylalcohol, and cellulose polymers such as Rayon. The porosities of these microcellular carbon foams were established by a variety of techniques including gelation, phase separation, emulsion, aerogel-xerogel formation, and replication. An electrolytic double-layer capacitor for energy storage based carbon aerogel, a type of carbon foam, was also developed by Lawrence Livermore National Laboratory [23]. The carbon aerogel electrodes used in this device had very high specific surface areas, ranging from 100 to $700 \mathrm{~m}^{2} / \mathrm{cm}^{3}$ and relatively low corresponding bulk densities, ranging from 0.3 to $1.0 \mathrm{~g} / \mathrm{cm}^{3}$. These characteristics made it 
possible to construct a device with a very high energy density. The electrical continuity of the material permits stored energy to be released rapidly, resulting in a relatively high power density $(\sim 7.5 \mathrm{~kW} / \mathrm{kg})$. Other composites of activated carbon powder and polymeric binders have also been developed for use as electrodes in electrochemical cells [24]. Even though these materials are made from activated carbon powders with very high specific surface areas $\left(600 \mathrm{~m}^{2} / \mathrm{gm}\right)$, much of the surface is occluded by the binder. Consequently, they do not have specific surface areas as great as carbon aerogel.

This paper discusses the capacitive deionization (CDI) of aqueous solutions with carbon aerogel electrodes. Some specific advantages of CDI with monolithic carbon aerogel electrodes include enhanced electrosorption capacity due to the accessibility of the immense specific surface area, as well as complete immobilization of the porous carbon matrix. Since the specific surface area of carbon aerogel is significantly greater than that of activated carbon powder appropriate for use in flow-through packed beds, a greater quantity of salt can be electrosorbed on carbon aerogel than on a comparable mass of activated carbon powder. Immobilization has made it possible to construct systems that do not require porous membrane separators. Unlike activated carbon powder, monolithic sheets of carbon aerogel are not entrained in the flowing fluid stream. The electrolyte flows in a channel between adjacent anodes and cathodes and does not experience the high pressure drop associated with flow through packed beds and porous media. Finally, less potential drop occurs in a thin sheet of carbon aerogel than in a relatively deep bed of activated carbon. Consequently, more ions can be electrosorbed on a unit of carbon aerogel surface area than on a comparable unit of activated carbon surface area. In deep packed beds of carbon, the potential can drop to levels where the electrosorption process is not very effective.

There are several important potential applications for CDI with carbon aerogel electrodes. Ion exchange is now used as a means for removing anions and cations, including heavy metals and radioisotopes, from process and waste water in various industries. This process generates large volumes of corrosive secondary wastes that must be treated for disposal through regeneration processes. After ion exchange columns are saturated, resins must be regenerated by pumping relatively concentrated solutions of acids, bases, or salts through the columns. These solutions become contaminated with ions removed from the resins and become part of a large inventory of secondary waste. Eventually, the resins also become part of the inventory of secondary waste. During plutonium processing, resins and solutions of $\mathrm{HNO}_{3}$ become contaminated with $\mathrm{PuO}_{2}{ }^{2+}$ and other radioisotopes. In this case, every kilogram of cation exchange resin requires approximately 100 kilograms of $10 \mathrm{wt}$. $\% \mathrm{HNO}_{3}$ and 2 to 3 kilograms of rinse water for regeneration. Similarly, every kilogram of used anion exchange resin requires approximately 100 kilograms of $10 \mathrm{wt} . \% \mathrm{NaOH}$ and 2 to 3 kilograms of rinse water for regeneration. Given the high and increasing cost of disposal of secondary wastes in mined geological repositories, there is tremendous and still unfulfilled need for reducing, and in certain applications, eliminating the volume of secondary wastes.

CDI could also be used to remove inorganic ions from boiler water for fossil and nuclear power plants. A variety of dissolved inorganic ions have to be removed to prevent scaling of heat exchanger surfaces and to prevent failure due to pitting and stress corrosion cracking. It might be possible to use CDI to remove radioactive ions from the contaminated waste water of nuclear power plants before discharge. Deionizers based on columns of zeolite, silica gel, and ion exchange resins were evatuated for the removal ${ }^{137} \mathrm{Cs}$, ${ }^{90} \mathrm{Sr}$, and ${ }^{125} \mathrm{Sb}$ from contaminated water at the Three Mile Nuctear Power Station Unit No. 2 [25]. As previously discussed, ion exchange cotumns require chemical regeneration and thereby produce large volumes of radioactive secondary waste. Eventually, the contaminated columns also become waste. Since CDI uses electrical regeneration, it may be ideal for such applications. 


\section{EXPERIMENTAL}

Conceptually, the CDI process is very simple. After application of a voltage between two adjacent carbon aerogel electrodes, cations and anions are drawn towards the cathode and anode, respectively. These ions are held in the electric double layers formed at the extensive surface of the carbon aerogel electrodes until the voltage is reduced. Double-sided electrodes are made by gluing two sheets of a carbon aerogel composite (CAC) to both sides of a titanium plate that serves as both a current collector and a structural support for the CAC. Conductive silver epoxy is used for gluing. CAC has an exceptionally high specific surface area of $600-800 \mathrm{~m}^{2} / \mathrm{gm}$. Each sheet of CAC is $6.86 \mathrm{~cm} \mathrm{x} 6.86 \mathrm{~cm} \mathrm{x} 0.0127 \mathrm{~cm}$ and has a total active surface of approximately $2.8 \times 10^{6} \mathrm{~cm}^{2}$. Two orifices are located along one side of the carbon aerogel electrode and admit water to the electrode gap. A pattern of holes are located around the perimeter of the titanium plate and accommodate 12 threaded rods that hold the cell stack together. A lower stainless steel header with a rubber gasket and 12 threaded rods; an array of electrodes, gaskets, and spacers; and an upper stainless steel header are assembled into a stack. Even electrodes serve as cathodes while odd electrodes serve as anodes. The electrodes and headers are aligned by the threaded rods. An electrode separation of $0.05 \mathrm{~cm}$ is maintained by cylindrical nylon spacers concentric with the threaded rods and a rubber compression seal. Since the orifices in each electrode alternate from one side of the stack to the other, the flow path through the stack is serpentine. A stack of 192 pairs of carbon aerogel electrodes have a total active cathodic (or anodic) surface area of approximately $1.1 \times 10^{9} \mathrm{~cm}^{2}$. Flow through the stack is generated by a programmable, magnetically-coupled, screw pump with a 304 stainless steel head. The pressure drop across a stack of 48 electrode pairs is only 5 psi at $1.7 \mathrm{~L} / \mathrm{min}$, whereas the drop across a stack of 192 electrode pairs is less than 14 psi at $1.5 \mathrm{~L} / \mathrm{min}$. All lines are made of Teflon and have a nominal diameter of $1 / 4 \mathrm{inch}$. The cells are polarized by programmable power supplies that have a voltage range of 0 to $12 \mathrm{~V}$ or a current range of 0 to $60 \mathrm{~A}$. Sensors are placed on the inlet and outlet lines of the electrode stack. Electrical conductivity, $\mathrm{pH}$, individual ion concentrations, and temperature are continuously monitored. A computerized data acquisition system logs important operating parameters such as voltage, current, conductivity, $\mathrm{pH}$, and temperature. Data acquisition system is based on an Intel 486DX-33 microprocessor, a National Instruments 8-channel $\mathrm{A} / \mathrm{D}$ converter, and LabTech Notebook data acquisition software for Microsoft Windows.

As previously discussed, electrodes are made from thin sheets of CAC glued to titanium plates with conductive epoxy. Carbon aerogels were developed at Lawrence Livermore National Laboratory [26,27]. The preparation of resorcinol-formaldehyde (RF) aerogels and their carbonized derivatives has been described previously [28-30]. For this study, carbon aerogel composite (CAC) electrodes were formed by infiltrating a $70 \% \mathrm{w} / \mathrm{v} \mathrm{RF}$ solution into a porous carbon paper (Lyndall Technical Papers, Rochester, NH). The RF/carbon paper was cured between glass plates in a closed vessel to prevent evaproation. Next, the RF/carbon paper was exchanged into acetone which was subsequently evaporated at room temperature. It should be noted that these electrodes were not supercritically dried, which is necessary for producing low density organic aerogels. Finally, the RF/carbon paper was pyrolyzed at $1050^{\circ} \mathrm{C}$ in a nitrogen atmosphere to give thin film electrodes $\left(\sim 125 \mathrm{~mm}\right.$ thick) having bulk densities of $\sim 0.6 \mathrm{~g} / \mathrm{cm}^{3}$. A thin film of graphite-filled epoxy (3:1:3 Epon 828: HY955: graphite) was then applied to the titanium current collectors, and the electrodes were lightly pressed into place. The epoxy was further cured for 24 hours at $85^{\circ} \mathrm{C}$. This fabrication process results in unique open-cell carbon foams that have high porosities, high specific surface areas $\left(400-1000 \mathrm{~m}^{2} / \mathrm{g}\right)$, ultrafine cell and pore sizes $(\leq 50 \mathrm{~nm}$ ), and a solid matrix composed of interconnected colloidal-like particles or fibrous chains with characteristic diameters of $10 \mathrm{~nm}$. 
Initial parametric studies were performed with solutions of $\mathrm{Na}_{2} \mathrm{SO}_{4}, \mathrm{Na}_{3} \mathrm{PO}_{4}$, or $\mathrm{Na}_{2} \mathrm{CO}_{3}$ in water. Results for $\mathrm{NaCl}$ and $\mathrm{NaNO}_{3}$ have been reported previously [31-32]. Cell voltages were $0.0,0.6,0.7,0.8,1.0$, and $1.2 \mathrm{~V}$. Batch-mode experiments were done by continuously recycling $4.0 \mathrm{~L}$ of electrolyte at a flow rate of $1.0 \mathrm{~L} / \mathrm{min}$. Single-pass experiments were done by pumping $20 \mathrm{~L}$ of electrolyte through the electrode stack at flow rate of $25-27 \mathrm{ml} / \mathrm{min}$ and involved no recycle. The solution conductivity was $100 \mu \mathrm{mho} / \mathrm{cm}$ in all cases reported here.

\section{Results}

Overall, tests demonstrated that $\mathrm{CDI}$ with carbon aerogel can $\mathrm{Na}_{2} \mathrm{SO}_{4}, \mathrm{Na}_{3} \mathrm{PO}_{4}$, and $\mathrm{Na}_{2} \mathrm{CO}_{3}$ from water. Deionization was accomplished during charging, while regeneration was accomplished during discharge. The concentration and conductivity of each solution was cycled up and down numerous times by charging and discharging the stack. The ability of the CAC electrodes to remove ions from water, e.g., the electrosorption capacity, had a strong dependence on cell voltage. The best results were achieved at $1.2 \mathrm{~V}$, with relatively poor performance below $0.6 \mathrm{~V}$. Breakthrough was observed during single-pass experiments without recycle.

Sodium Sulfate Solutions Batch-mode experiments with complete recycle were conducted with a solution of $\mathrm{Na}_{2} \mathrm{SO}_{4}$ in water that had an initial conductivity slightly greater than 100 $\mu \mathrm{mho} / \mathrm{cm}$ (approximately $100 \mathrm{ppm}$ ). The electrochemical cell was constructed from 192 pairs of aged carbon aerogel electrodes, electrodes that had been cycled several months with $\mathrm{NaCl}$ and $\mathrm{NaNO}_{3}$ solutions. The volume of electrolyte was $4.0 \mathrm{~L}$ and the flow rate through the stack of electrodes was $1.0 \mathrm{~L} / \mathrm{min}$. Transients in solution conductivity during batch-mode experiments with $\mathrm{Na}_{2} \mathrm{SO}_{4}$ at four different applied voltages, $0.6,0.8,1.0$, and $1.2 \mathrm{~V}$ are shown in Fig. 1.

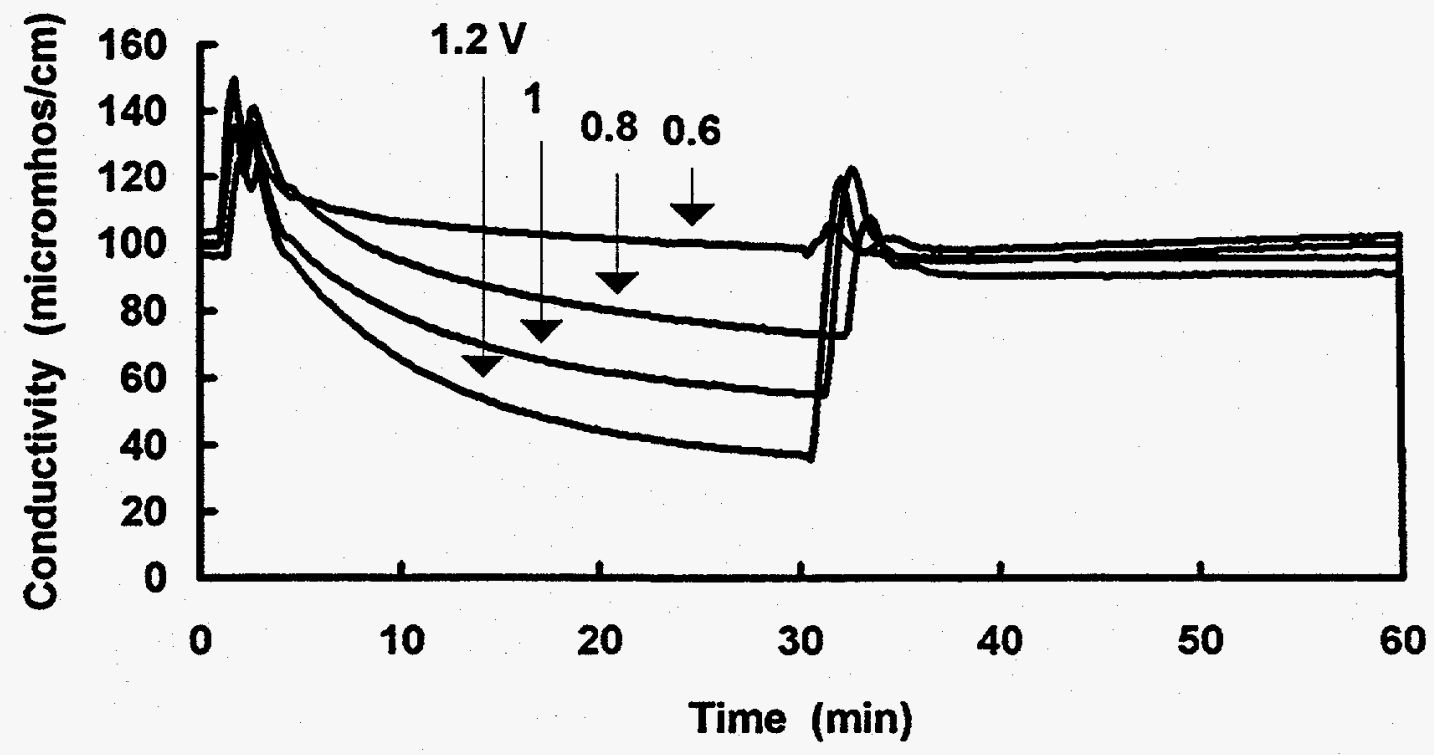

Fig. 1. Batch mode experiment with sodium sulfate at 0.6-1.2 V.

As expected, cations and anions were held in the electric double layers formed at the extensive surfaces of the carbon aerogel cathodes and anodes during charging and released back into the electrolyte during discharge. Consequently, the salt concentration dropped during charging and increased during discharge. The greater the cell voltage, the greater the extent of deionization. Reductions in solution conductivity were $0,27,44$, and $65 \%$ at $0.6,0.8,1.0$, and $1.2 \mathrm{~V}$, respectively. The process was reasonably effective at $1.2 \mathrm{~V}$, with relatively poor performance at lower voltages. Electrosorption capacity decreased as the cell voltage was 
lowered. The initial peak in solution conductivity observed during cell charging appears to be a characteristic of aged electrodes that is believed to be due to the voltage-induced release of ions trapped in the carbon aerogel matrix. Such peaks are not usually observed with new or electrically rejuvenated electrodes $[31,32,35]$. It appears that periodic voltage reversal can be used to drive such trapped ions from the carbon aerogel, thereby improving the cell performance dramatically. Such voltage reversal is known as electrical rejuvenation. The improvement possible through voltage reversal is evident from the $\mathrm{Na}_{2} \mathrm{CO}_{3}$ experiments discussed subsequently. The experiments with $\mathrm{Na}_{2} \mathrm{CO}_{3}$ were performed after those with $\mathrm{Na}_{2} \mathrm{SO}_{4}$.

Sodium Phosphate Solutions Batch-mode experiments with complete recycle were conducted with a solution of $\mathrm{Na}_{3} \mathrm{PO}_{4}$ in water that had an initial conductivity slightly greater than $100 \mu \mathrm{mho} / \mathrm{cm}$ (approximately $100 \mathrm{ppm}$ ). The electrochemical cell, the volume of electrolyte, and the flow rate were identical to those described for the $\mathrm{Na}_{2} \mathrm{SO}_{4}$ experiment. Here too aged electrodes were used. Transients in solution conductivity during batch-mode experiments with $\mathrm{Na}_{3} \mathrm{PO}_{4}$ at four different applied voltages, $0.6,0.8,1.0$, and $1.2 \mathrm{~V}$ are shown in Fig. 2.

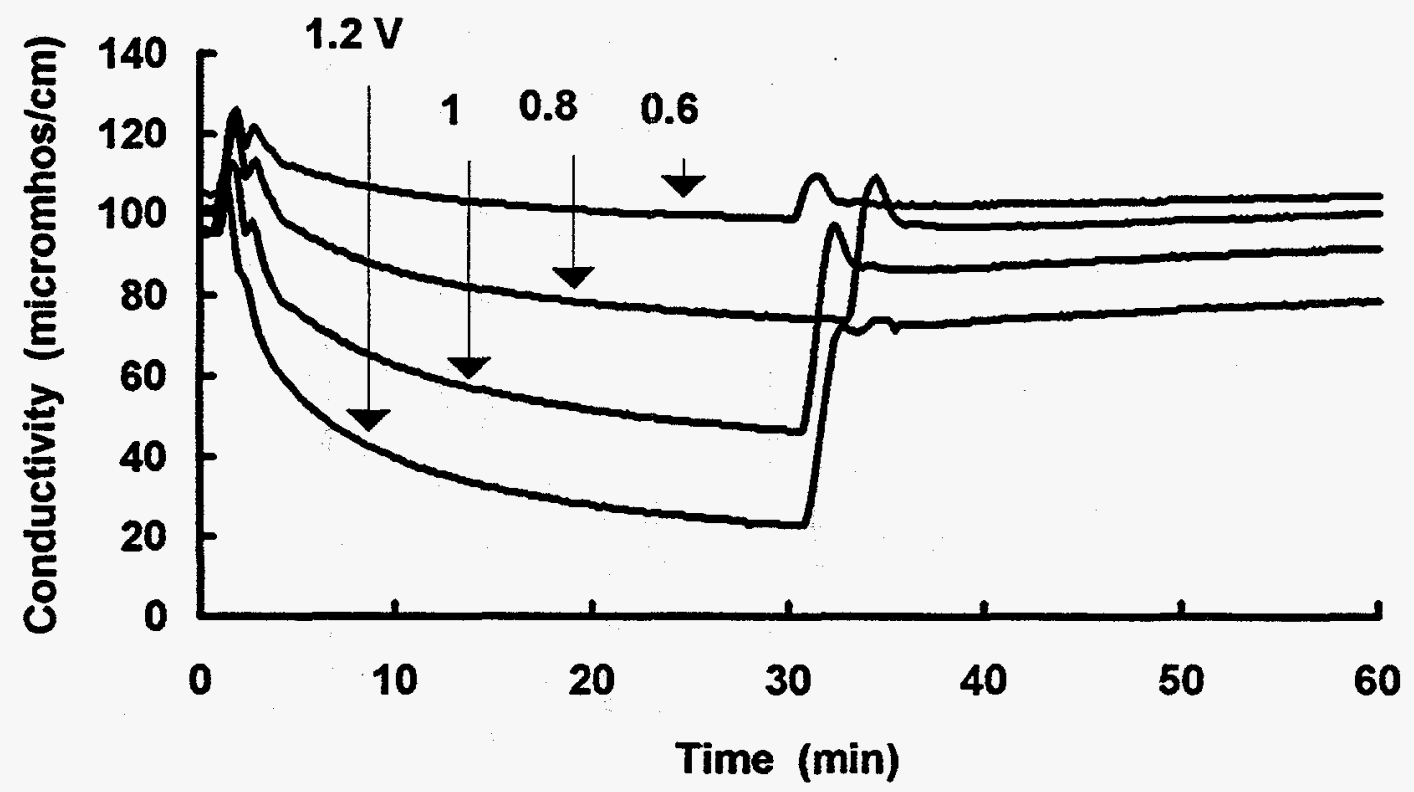

Fig. 2. Batch mode experiment with sodium phosphate at 0.6-1.2 V.

As expected from experiments with $\mathrm{NaCl}, \mathrm{NaNO}_{3}$, and $\mathrm{Na}_{2} \mathrm{SO}_{4}$, cations and anions were held in the electric double layers formed at the extensive surfaces of the carbon aerogel cathodes and anodes during charging and released back into the electrolyte during discharge. Consequently, the salt concentration dropped during charging and increased during discharge. The greater the cell voltage, the greater the extent of deionization. Reductions in solution conductivity were $0,27,51$, and $76 \%$ at $0.6,0.8,1.0$, and $1.2 \mathrm{~V}$, respectively. The process was very effective at $1.2 \mathrm{~V}$, with much poorer performance at $0.6 \mathrm{~V}$. Electrosorption capacity decreased as the cell voltage was lowered. A breakthrough curve from a single-pass experiment with $100 \mu \mathrm{mho} / \mathrm{cm} \mathrm{Na}_{3} \mathrm{PO}_{4}$ solution is shown in Fig. 3. The cell voltage was $1.2 \mathrm{~V}$ and the flow rate was $25 \mathrm{ml} / \mathrm{min}$. The outlet concentration, measured as conductivity, dropped to a very low level immediately after polarization of the carbon aerogel electrodes. Two increases in conductivity were observed, one beginning between 60 and 90 minutes and another beginning at approximately 300 minutes. This may be due to the simultaneous elution of multiple phosphate species $\left(\mathrm{H}_{2} \mathrm{PO}_{4}^{-}, \mathrm{HPO}_{4}^{-}\right.$, and $\left.\mathrm{PO}_{4}^{-}\right)$in the electrode stack. Such 
complicated breakthrough curves are not observed with monovalent salts such as $\mathrm{NaCl}$ and $\mathrm{NaNO}_{3}$ [31-32]. Once again the apparant drop in inlet conductivity is an artifact, possibly due to trapped air in the inlet conductivity sensor near the end of the experiment. Some irreversibility was abserved in the electrosorption of phosphate on the CAC electrodes.

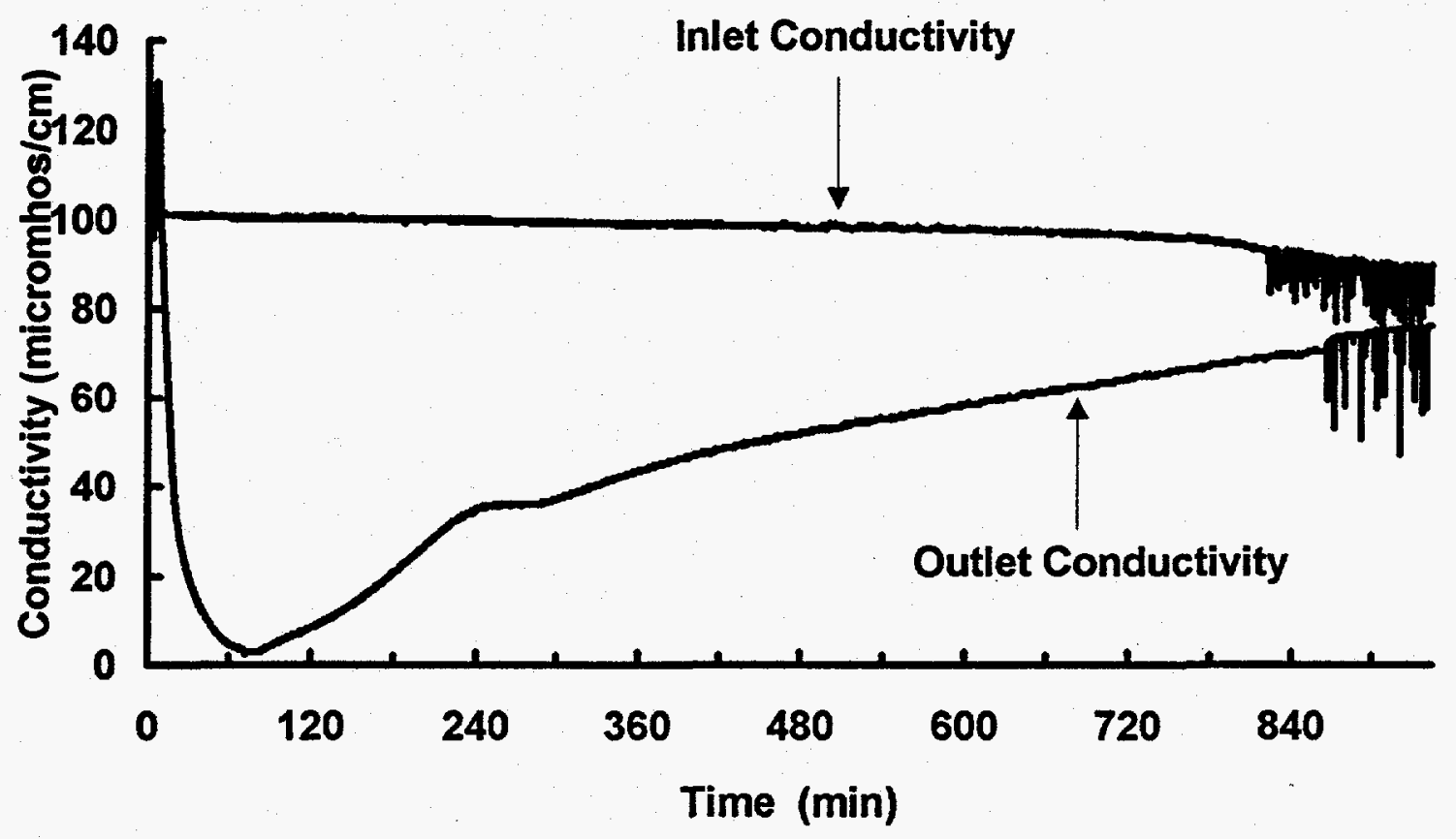

Fig. 3. Single-pass experiment with sodium phosphate at $1.2 \mathrm{~V}$.

Sodium Carbonate Solutions Batch-mode experiments with complete recycle were conducted with a solution of $\mathrm{Na}_{2} \mathrm{CO}_{3}$ in water that had an initial conductivity slightly greater than $100 \mu \mathrm{mho} / \mathrm{cm}$ (approximately $100 \mathrm{ppm}$ ). The electrochemical cell, the volume of electrolyte, and the flow rate were identical to those described for the $\mathrm{Na}_{2} \mathrm{SO}_{4}$ experiment, except for the electrical-rejuvenation of the electrodes. Transients in solution conductivity during batch-mode experiments with $\mathrm{Na}_{2} \mathrm{CO}_{3}$ at four different applied voltages, $0.6,0.8,1.0$, and $1.2 \mathrm{~V}$ are shown in Fig. 4. As expected, cations and anions were held in the electric double layers formed at the extensive surfaces of the carbon aerogel cathodes and anodes during charging and released back into the electrolyte during discharge. Consequently, the salt concentration dropped during charging and increased during discharge. The greater the cell voltage, the greater the extent of deionization. Reductions in solution conductivity were 63, 80,89 , and $96 \%$ at $0.6,0.8,1.0$, and $1.2 \mathrm{~V}$, respectively. The process was very effective at $1.2 \mathrm{~V}$, with relatively poor performance at $0.6 \mathrm{~V}$. Electrosorption capacity decreased as the cell voltage was lowered. A breakthrough curve from a single-pass experiment with 100 $\mathrm{mmho} / \mathrm{cm} \mathrm{Na}_{2} \mathrm{CO}_{3}$ solution is shown in Fig. 5. The cell voltage was $1.2 \mathrm{~V}$ and the flow rate was $27 \mathrm{ml} / \mathrm{min}$. The outlet concentration, measured as conductivity, dropped to a very low level immediately after polarization of the carbon aerogel electrodes. Two increases in conductivity were observed, one beginning at approximately 180 minutes and another beginning at approximately 600 minutes. This may be due to the simultaneous elution of two carbonate species $\left(\mathrm{HCO}_{3}{ }^{-}\right.$and $\left.\mathrm{CO}_{3}{ }^{-}\right)$in the electrode stack. The apparant drop in inlet conductivity is an artifact, possibly due to air in the conductivity sensor. 


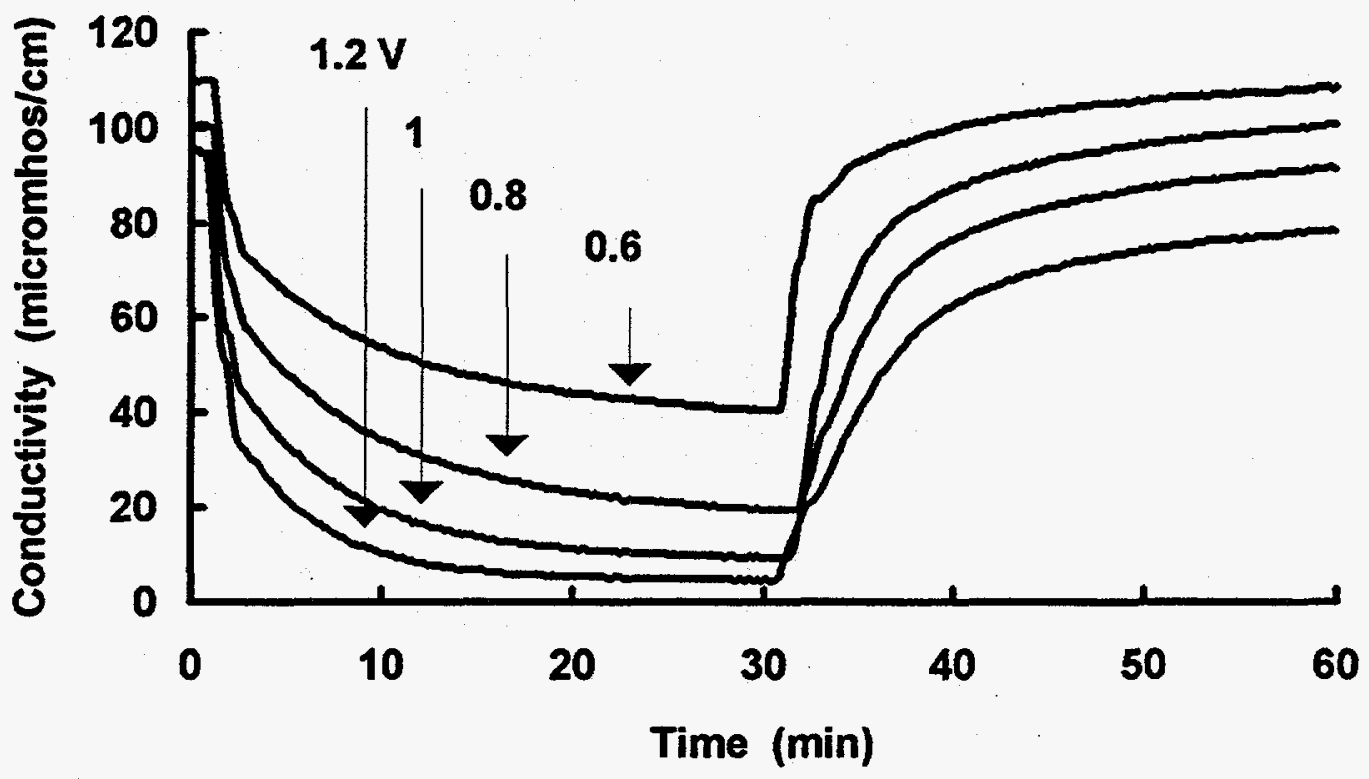

Fig. 4. Batch mode experiment with sodium carbonate at $0.6-1.2 \mathrm{~V}$.

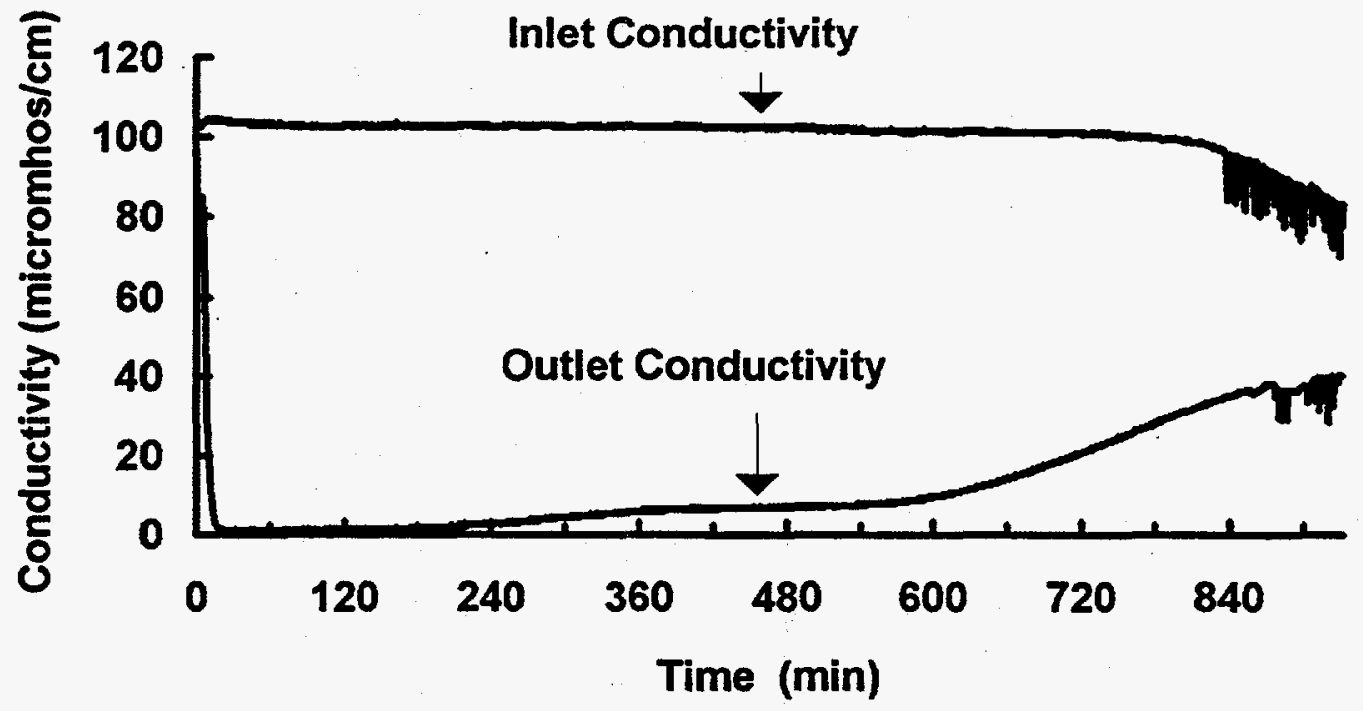

Fig. 5. Single-pass experiment with sodium carbonate at $1.2 \mathrm{~V}$.

Electrical Rejuvenation Electrical rejuvenation is discussed in another paper [35]. In general, electrosorption capacity (salt removal) decreases with cycle life. After months of operation with $\mathrm{NaCl}$ and $\mathrm{NaNO}_{3}$, the electrodes lost $6-8 \%$ of their capacity at $1.2 \mathrm{~V}$. The effect was more pronounced at lower cell voltages. However, it appeared that most of the loss in capacity could be recovered by periodically reversing the electrode polarization (rejuvenation). These problems are reminiscent to those discussed by Johnson [12]. Additional aging studies should be performed to quantify electrode life more precisely.

\section{CONCLUSIONS}

The capacitive deionization (CDI) of aqueous solutions of $\mathrm{Na}_{2} \mathrm{SO}_{4}, \mathrm{Na}_{3} \mathrm{PO}_{4}$, and $\mathrm{Na}_{2} \mathrm{CO}_{3}$ with carbon aerogel electrodes has been demonstrated for the first time. Cell voltages ranging from 0.6 to $1.2 \mathrm{~V}$ were investigated. As expected, the best performance (salt removal) was achieved at $1.2 \mathrm{~V}$. Periodic voltage reversal was necessary to maintain high electrosorption 
capacity. In experiments with electrically-rejuvenated carbon aèrogel electrodes, $96 \%$ of the $\mathrm{Na}_{2} \mathrm{CO}_{3}$ was removed from a fixed volume of $100 \mu \mathrm{mho} / \mathrm{cm}$ electrolyte. Greater removal was achieved in single-pass experiments. Relatively complicated breakthrough curves were observed in single-pass experiments with both $\mathrm{Na}_{3} \mathrm{PO}_{4}$ and $\mathrm{Na}_{2} \mathrm{CO}_{3}$. Such complexities were not observed in previous studies with monovalent anions and are attributed to the coexistence of several ionic species. If fully developed, carbon aerogel CDI might serve as an alternative to conventional ion exchange, thereby avoiding the generation of a large volume of secondary waste due to the chemical regeneration of ion exchange resins. The energy efficiency of the process may also make it desirable for some desalination applications. However, more detailed studies of electrode aging and fouling are essential.

\section{ACKNOWLEDGMENTS}

Funding for this project was provided by the Strategic Environmental Research and Development (SERDP) Program. This work was done under the auspices of the U.S. Department of Energy (DOE) by Lawrence Livermore National Laboratory (LLNL) under Contract No. W-7405-Eng-48.

\section{REFERENCES}

1. Trainham, J. A., Newman, J., "Flow-Through Porous Electrode Model: Application to Metal-Ion Removal from Dilute Streams," J. Electrochem. Soc. 12410 (1977) 1528-1540.

2. Van Zee, Newman, J., "Electrochemical Removal of Silver Ions from Photographic Fixing Solutions Using a Porous Flow-Through Electrode," J. Electrochem. Soc. 1245 (1977) 706-708

3. Moeglich, K., "Apparatus for Removal of Contaminants from Water," U. S. Pat. No. 4,072,596, February 07, 1978.

4. Blaedel, W. J., Wang, J. C., "Flow Electrolysis on a Reticulated Vitreous Carbon Electrode," Anal. Chem. 517 (1979) 799-802.

5. Risch, T., Newman, J., "Flow-Through and Flow-By Porous Electrodes at the Limiting Current," J. Electrochem. Soc. 13111 (1984) 2551-2556.

6. Lessner, P.; Newman, J., "Hydrodynamics and Mass Transfer in a Porous-Wall Channel," J. Electrochem. Soc. 1318 (1984) 1828-1831.

7. Platek, G. F., "Reticulate Electrode for Recovery of Metal Ions," U. S. Pat. No. 4,515,672, May 07, 1985.

8. Matlosz, M., Newman, J., "Experimental Investigation of a Porous Carbon Electrode for the Removal of Mercury from Contaminated Brine," J. Electrochem. Soc., 1339 (1986) 1850-1859.

9. Caudle, D. D., Tucker, J. H., Cooper, J. L., Arnold, B. B., Papastamataki, A., "Electrochemical Demineralization of Water with Carbon Electrodes," Research Report, Oklahoma University Research Institute, May 1966, 205 p.

10. Murphy, G. W., Bloomfield, J. J., Smith, F. W., Neptune, W. E., Caudle, D.D., "Demineralization of Saline Water by Electrically-Induced Adsorption of Porous Carbon Electrodes," Oklahoma University Research Institute.

11. Johnson, A. M.; Venolia, A. W.; Newman, J., Wilbourne, R. G.; Wong, C. M.; Gillam, W. S., Johnson, S., Horowitz, R. H., "Electrosorb Process for Desalting Water," Office of Saline Water Research and Development Progress Report No. 516, U.S. Dept. Interior Pub. 200 056, March 1970, 31 p.

12. Johnson, A. M., Venolia, A. W., Wilbourne, R. G., Newman, J., "The Electrosorb Process for Desalting Water," Marquardt Co., Van Nuys, CA, March 1970, 36 p. 
13. Johnson, A. M., "Electric Demineralizing Apparatus," U.S. Pat. No. 3,755,135, August 28, 1973.

14. Johnson, A. M., Newman, J., "Desalting by Means of Porous Carbon Electrodes," J. Electrochem. Soc., 1183 (1971) 510-517.

15. Oren, Y., "Electrochemical Parametric Pumping," Ph.D. Dissertation, Weizmann Inst. of Science, Rehovoth, Israel, March 1983, 111 p.

16. Oren, Y.; Soffer, A., "Water Desalting by Means of Electrochemical Parametric Pumping: II. Separation Properties of a Multistage Column," J. Appl. Electrochem. 134 (1983) 489-505.

17. Oren, Y., Soffer, A., "Water Desalting by Means of Electrochemical Parametric Pumping: I. The Equilibrium Properties of a Batch Unit Cell," J. Appl. Electrochem. 13 4 (1983) 473-487.

18. Katsu, Keitaro, "Double Layer Electric Capacitor," Nippon Electric Co., Jap. Pat. Appl. 91-303689.

19. "Electric Double-layer Capacitor," Matsushita Electric Industrial Co., Ltd., Jap. Pat. Appl. 83-89451.

20. Tabuchi, J., Kibi, Y., Saito, T., Ochi, A., "Electrochemical Properties of Activated Carbon/Carbon Composites for Electric Double-layer Capacitor in New Sealed Rechargeable Batteries and Supercapacitors," presented at the 183rd Electrochem. Soc. Mtg., Honolulu, HI, May 16-21, 1993.

21. "Electrical Double-layer Capacitor, Uses Porous Polarized Electrode Consisting of Carbonized Foamed Phenol Resin," Mitsui Petrochem Ind., Jap. Pat. Appl. 89-210642.

22. Delnick, F. M., Ingersoll, D., Firsich, D., "Double-layer Capacitance of Carbon Foam Electrodes," SAND-93-2681, Sandia National Laboratory, Albuquerque, NM, 1993, 10 p.

23. Mayer, S. T., Pekala, R. W., Kaschmitter, J. L., "The Aerocapacitor: An Electrochemical Double-layer Energy-Storage Device," J. Electrochemical Society 1402 (1993) 446-451.

24. Wessling, B, Volk, H., Hilleberg, M., Funder, C., Siemers, O., Merkle, H., "Stable Electrode for Electrolytic Process (Desalination and Drying) Contains Thermoplastic Polymer and Material Giving conductivity and Stable Potential," U. S. Pat. No. 4806212.

25. Campbell, D.O., Collins, E.D., King, L.J., Knauer, J.B., "Process improvement studies for the Submerged Demineralizer System (SDS) at the Three Mile Island Nuclear Power Station, Unit 2," ORNL/TM-7756, Oak Ridge National Laboratory, Oak Ridge, TN, May $1982,30 \mathrm{p}$.

26. Wang, J., et al., "Carbon Aerogel Composite Electrodes," Anal. Chem. 65 (1993) 23002303.

27. Pekala, R. W., et al., "Supercapacitors Based on Carbon Foams," U.S. Pat. No. $5,260,855$.

28. Pekala, R.W., Alviso, C. T., in Novel Forms of Carbon, Renschler, C. L., Pouch, J. J., and Cox, D. M., Eds., MRS Symp. Proc. 2703 (1992).

29. Pekala, R. W., in Ultrastructure Processing of Advanced Materials, Uhlmanjn, D. R., Ulrich, D. R., Eds., John Wiley and Sons, Inc., New York, NY, 1992, pp. 711-717.

30. Pekala, R. W., Mayer, S. T., Poco, J. F., Kaschmitter, J. L., "Structure and Performance of Carbon Aerogel Electrodes," Novel Forms of Carbon II, Renschler, C. L., Cox, D. M., Pouch, J. J., Achiba, Y., Eds., MRS Symp. Proc. 34979 (1994).

31. Farmer, J. C., Fix, D. V., Mack, G. V., Pekala, R. W., Poco, J. F., "The Use of Capacitive Deionization with Carbon Aerogel Electrodes to Remove Inorganic Contaminants from Water," in Proceedings of the 1995 International Low Level Conference. Advanced Wet Waste Processing and Technology, Orlando, Florida, July 10-12, 1995, Electric Power Research Institute (EPRI), Palo Alto, CA. 
32. Farmer, J. C., Fix, D. V., Mack, G. V., Pekala, R. W., Poco, J. F., "Capacitive Deionization of Water: An Innovative New Process," in Proceedings of the Fifth International Conference on Radioactive Waste Management and Environmental Remediation, Berlin, Germany, September 3-9, 1995, American Society of Mechanical Engineers, New York, NY.

33. King, C. J., Separation Processes, 2nd Ed., McGraw-Hill, San Francisco, CA, 1980, pp. 661-664.

34. Newman, J. S., Electrochemical Systems, 2nd Ed., Prentice Hall, Englewood Cliffs, NJ, 1991, pp. 89-94.

35. Farmer, J. C., Fix, D. V., Mack, G. V., Pekala, R. W., Poco, J. F., "Capacitive Deionization of $\mathrm{NaCl}$ and $\mathrm{NaNO}_{3}$ Solutions with Carbon Aerogel Electrodes," submitted to J. Electrochemical Society. 